\title{
Immunohistochemical expression of interleukin-17 and hormonal receptors in benign and malignant breast lesions
}

\author{
Eman Taha Ali ${ }^{1} 2^{*}$, Mai Abdulrahman Mohammed Masri ${ }^{3}$, Emmanuel Edwar Siddig $^{4,5,6}$, Ayman Ahmed $^{7}$, \\ Mohamed S. Muneer $8,9,10$, Nouh Saad Mohamed ${ }^{11,12,13}$ and Ali Mahmoud Mohammed Edris ${ }^{1,14}$
}

\begin{abstract}
Objectives: IL17 is a critical pro-inflammatory cytokine that is involved in inflammation, multidrug resistance and growth persistence pathways in cancer. This study is aiming at studying the expression of IL 17 and hormonal receptors expression in benign and malignant breast lesions using immunohistochemical staining methods.

Results: A total of 137 cases of breast lesions were studied, 97 (70.8\%) were malignant and 40 (29.2\%) were benign cases. Age range for malignant and benign cases were between 26 and 80 years [mean age $50 \pm 2$ years], and 20 to 70 years [mean age $41 \pm 4$ years], respectively, Odds ratio $=2.3[1.78-1.99,95 \% \mathrm{Cl}]$. The majority of the histopathological diagnosis of the benign and malignant lesions were 21 (15.3\%) fibro-adenomas and 87 (63.5\%) invasive ductal carcinoma, respectively. Expression of IL 17 and age were insignificantly negatively correlated for both groups; benign cases $[r=-0.054, P$ value 0.742$]$ and malignant cases $[r=-0.080, P$ value 0.444$]$. IL 17 expression was showing insignificant association with age group, P value 0.065. IL17 expression showed a statistical significance based on the different histopathological diagnosis, $P$ value 0.035 . Expression levels of estrogen, progesterone, and human epidermal receptors were showing insignificant difference among IL17 expression categories, P values $0.678,0.623$, and 0.361, respectively.
\end{abstract}

Keywords: Interleukin-17, Immunohistochemistry, Breast lesions, Breast cancer

\section{Introduction}

Breast cancer $(\mathrm{BC})$ is one of the global prevalent malignancies among females [1]. According to 2019 cancer statistics, the incidence of $\mathrm{BC}$ is surprisingly increasing compared to earlier reports in 2018. Not surprisingly, the rate of mortality is very high in the African developing countries owing to socioeconomic factors [2]. Importantly, the majority of women in these countries were diagnosed at late stages of the disease that ominously, has been metastasized [2]. In a previous study, among 120

\footnotetext{
*Correspondence: eman2taha@gmail.com

${ }^{2}$ Department of Histopathology and Cytology, Faculty of Medical

Laboratory Sciences, National University, Khartoum, Sudan

Full list of author information is available at the end of the article
}

patients diagnosed with benign lesion and were followed up for almost 20 years, $34 \%$ of all palpable lesions were found to be malignant tumors followed by fibro-adenoma (28\%), fibrocystic diseases (11\%), inflammatory changes (11\%), and other phylloid tumors and lactation changes (6\%) [3]. According to the WHO there are several features in present in the benign lesions that are well known as pre-cancerous signs [4].

Metastasis and drug resistance constitute important problems in BC management and survival as well [5]. Lately, studies investigated the role of cytokines expression among both benign and malignant cancer patients, their finding was quite unique to further investigate the role of cytokines expression to understand the invasion

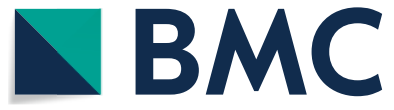

(c) The Author(s) 2020. This article is licensed under a Creative Commons Attribution 4.0 International License, which permits use, sharing, adaptation, distribution and reproduction in any medium or format, as long as you give appropriate credit to the original author(s) and the source, provide a link to the Creative Commons licence, and indicate if changes were made. The images or other third party material in this article are included in the article's Creative Commons licence, unless indicated otherwise in a credit line to the material. If material is not included in the article's Creative Commons licence and your intended use is not permitted by statutory regulation or exceeds the permitted use, you will need to obtain permission directly from the copyright holder. To view a copy of this licence, visit http://creativeco mmons.org/licenses/by/4.0/. The Creative Commons Public Domain Dedication waiver (http://creativecommons.org/publicdomain/ zero/1.0/) applies to the data made available in this article, unless otherwise stated in a credit line to the data. 
mechanism, then as diagnostic and prognostic markers for cancer development $[6,7]$.

Recently, cytokines and other ligands of immune system have been reported as instrumental factors in tumor microenvironment, and many of them are considered as prognostic and therapeutic targets in cancer [8, 9]. Basically, Interleukin-17 (IL17) is one of these important mediators which have strong potential mechanism to induce inflammation by enhancing neutrophil migration, angiogenesis, and matrix metalloproteinase production [10-12]. Furthermore, IL17 can induce other important signaling pathways in tumor cell itself such as Kras and epithelial-mesenchymal transition which were reported as imperative pathways in cancer growth and metastasis [12-14]. IL17 was also involved by triggering several pathways in tumor that lead to growth persistence against cancer therapy [15].

Status of steroid and growth factor receptors expression such as Estrogen Receptor (ER), Progesterone Receptor (PR), and Hunan Epidermal Receptor-2 (HER2) play a key role in term of diagnosis and treatment of BC [16-18], since $I L 17$ is directly related to production of steroid hormones and growth factors [9, 19, 20]. Consequently, the production of IL17 in tumor microenvironment suggested to play other significant clinical roles in BC development $[9,19,20]$. Previous facts indicate a crucial role of IL17 in cancer initiation, prognosis and treatment. Therefore, giving great interest to study its expression in benign and malignant breast lesions and with this background our current study is aiming at studying the expression of ILI7 and hormonal expression in benign and malignant breast lesions using Immunohistochemical staining Methods (IHC).

\section{Main text}

\section{Materials and methods}

\section{Study design and sample collection}

A descriptive cross-sectional hospital-based study conducted in National Central Khartoum Lab between 2017 and 2018. Simple random sampling method has been done; to collect Archival paraffin blocks from 127 female patients diagnosed with any type of breast lesion. Patients' age and diagnosis were obtained from hospital's record. Cancer grade and immunohistochemical expression of ER, PR, and HER2 for malignant cases were also obtained from the records which are done according to automated Ventana Benchmark XT system. ER and PR were graded using Allred scoring system [21]. HER2 was evaluated based on the membranous staining intensity according to Wolff et al., 2007 [22].

\section{Paraffin sections preparation and Immunohistochemical Technique}

One paraffin sections of 3-5 micrometers thickness was cut for IHC staining using rotary microtome. Immunohistochemical expression of IL17 was detected according to manufacturer instructions using the commercially available kit Mouse and Rabbit specific HRP/DAB Detection kit (ab64264, Abcam, Cambridge, UK). Briefly, tissue sections were de-waxed by xylene and rehydrated through gradients ethanol into water. For antigen retrieval, sections were heated in Citrate buffer ( $\mathrm{pH}$ 6.0) for $20 \mathrm{~min}$ at $95{ }^{\circ} \mathrm{C}$ and quenched for endogenous peroxidase activity using $3 \% \mathrm{H}_{2} \mathrm{O}_{2}$ in methyl alcohol. Sections were then washed in phosphate buffer saline (PBS) and the nonspecific binding of protein and antibody was blocked using protein block, then protein block was blotted off. Sections were incubated overnight at $4{ }^{\circ} \mathrm{C}$ with primary antibody against $I L 17$ (ab136668) at 1:100 dilution, after adjustment of the dilution and incubation period by using tonsil as a positive control for this antigen. After that, sections were washed with PBS then incubated with biotinylated secondary antibody. After several proper washes with washing buffer, the color was developed using HRP/DAP kit. Sections were lightly counterstained with hematoxylin and blued by running tap water, followed by dehydration and mounting in DPX.

\section{Immunohistochemical scoring system}

The cytoplasmic staining scoring for IL17 in all tissue sections was performed semi-quantitatively based on the overall intensity of staining on the cytoplasm by two different pathologists into no expression, mild expression, moderate expression, and strong expression, according to the overall percentage of stained cells; no cells express the $I L 17,10-30 \%$ of cells express $I L 17,40-60 \%$ of cells express $I L 17,60-80 \%$ of cells express $I L 17$, and $>80 \%$ of the cells express $I L 17$, respectively.

\section{Statistical analysis}

Data were analysed using the Statistical Package for Social Science (SPSS, v16). Chi Square test was used to analyze different categories a $P$ value of $<0.05$ was considered statistically significant. Pearson correlation of IL17 expression in regards to age of cases and hormonal receptors expression besides Odds ratios were also calculated.

\section{Results}

\section{Patients demographics and sample categorization}

The present study included 137 cases of breast lesions. Their age ranged between 20 and 80 years [mean age of $47 \pm 2$ years]. Notably, the age group 41 to 60 years 
constituted the majority of studied population; 85 (62.0\%). When categorizing the breast lesions-based malignancy, a total of $97(70.8 \%)$ were malignant and $40(29.2 \%)$ were benign. The malignant cases their age ranged between 26 and 80 years [mean of $50 \pm 2$ years], whereas, the benign cases their age ranged between 20 and 70 years [mean age of $41 \pm 4$ years], Odds ratio $=2.3$ [1.78-1.99, 95\% CI].

The benign cases based on the histopathological diagnosis included; fibro-adenomas (FA) which constituted the vast majority of the benign lesions 21 (15.3\%), followed by duct ectasia (DE) 11 (8.0\%), fibrocystic change (FC) 4 (2.9\%), lipoma 2 (1.5\%), and benign phyllodes tumor (PTS) 2 (1.5\%). While the malignant cases included $87(63.5 \%)$ cases reported as invasive ductal carcinoma (IDC), 7 (5.1\%) cases were invasive lobular carcinoma (ILC) and 3 (2.2\%) cases were intraductal carcinoma in situ (IDCS). The type of breast lesion was statistically significant with age group, P value 0.003 as well, classification based on the histopathological examination was showing significant association when grouped according to age group, P value 0.000 .

\section{IL17 immunohistochemical expression}

The expression of IL17 and age of cases were insignificantly negatively correlated for both groups; benign cases $[\mathrm{r}=-0.054, \mathrm{P}$ value 0.742$]$ and malignant cases $[\mathrm{r}=-0.080$, $\mathrm{P}$ value 0.444$]$. The levels of IL17 expression among cases aged between 41 and 60 years, more than
60 years, and between 21 and 40 years were $29.4 \%$ strong, $47.1 \%$ moderate, and $16.7 \%$ mild, respectively. IL17 expression was showing insignificant association when categorized based on age groups, P value 0.065 .

IL17 expressed in 63/97 (64.9\%) of the malignant cases and $17(42.5 \%)$ of the benign cases. Mild expression of IL17 was noted among $22(22.7 \%)$ of the malignant cases, while moderate expression was recorded among $10(25.0 \%)$ of the benign cases and $15(15.5 \%)$ of the malignant cases. Whereas benign and malignant cases recorded to show strong IL17 expression were 7 (17.5\%) and 26 (26.8\%), respectively (Fig. 1). A statistical significance was noted for the different expression categories among the benign and malignant cases, $P$ value 0.002 .

A strong expression of IL17 in malignant tissue sections was $28.7 \%$ among DC cases and $33.3 \%$ in IDC cases. For ILC cases, mild and moderate expression of IL17 was $28.6 \%$ for each. However, among the benign cases, DE and FA were mostly showing moderate expression; $36.4 \%$ and $28.6 \%$, respectively. While PTS and FC were showing strong expression; $100 \%$ and $50.0 \%$, correspondingly. Benign cases which diagnosed histopathologically as lipoma did not showed any expression of IL17.

IL17 expression showed a statistical significance based on the different histopathological diagnosis, $\mathrm{P}$ value 0.035 . With respect to hormonal receptors expression, the expression levels of ER, PR, and HER2 were showing insignificant difference among the different IL17 expression categories, $\mathrm{P}$ values $0.678,0.623$, and 0.361 ,

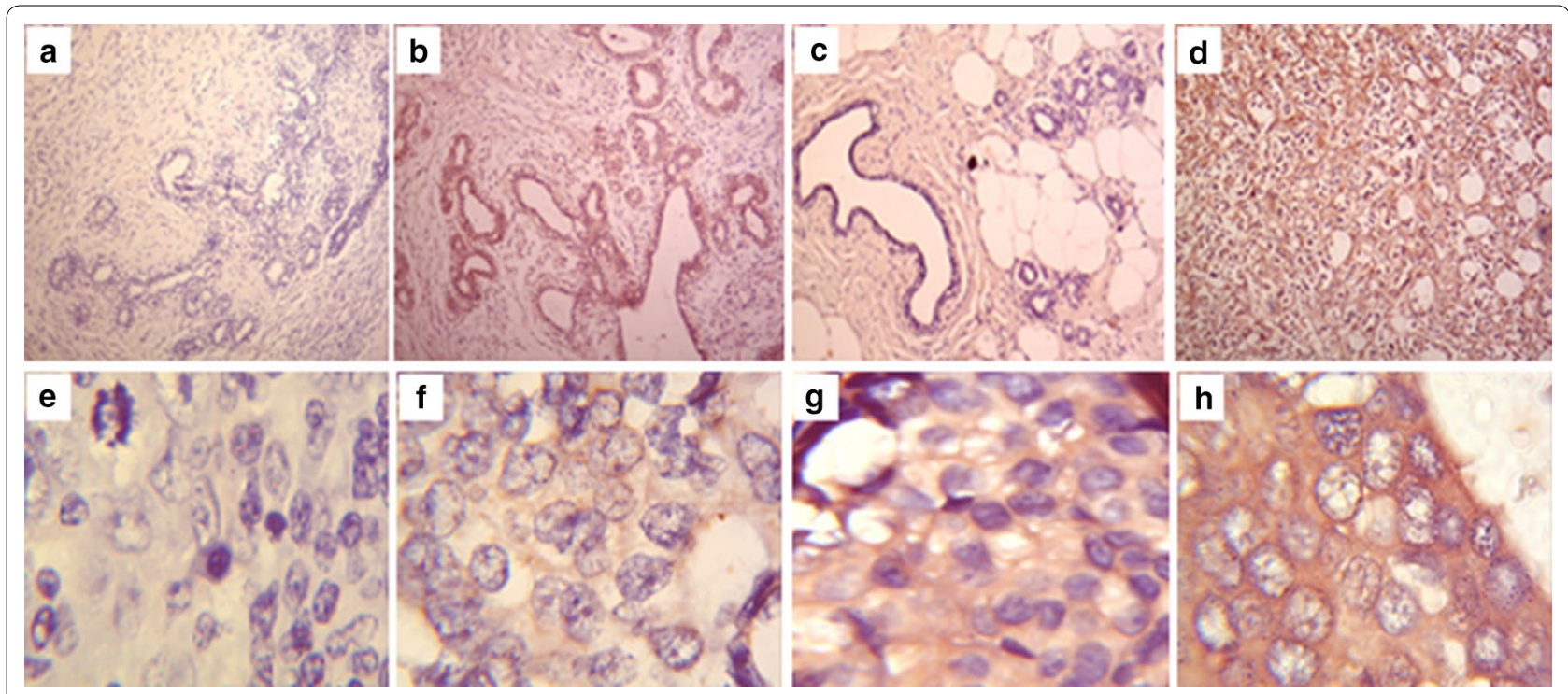

Fig. 1 Immunohistochemical expression of IL17 in malignant and benign tissues. Sections stained with Mayer's hematoxylin-DAP peroxidase. Microscopic magnification $\times 10$; a negative benign FA section, $\mathbf{b}$ positive benign FA section, $\mathbf{c}$ negative malignant IDC section, and $\mathbf{d}$ positive malignant IDC section. Microscopic magnification $\times 40$; e negative malignant IDC section, $\mathbf{f}$ mild positive malignant IDC section, $\mathbf{g}$ moderately positive malignant IDC section, $\mathbf{h}$ strongly positive malignant IDC section 
respectively. The results of $I L 17$ expression based on age groups, tumor type, histopathological diagnosis and hormonal receptors were illustrated in Table 1.

Concerning the correlation of ER, PR, and HER2 expression and IL17 expression in the breast lesions, no statistically significance correlation was shown for these receptors and IL17 expression (Table 2).

\section{Discussion}

Pro-inflammatory cytokines play a key role in cancer microenvironment and were associated with bad prognosis in breast cancer [7-9]. The current study has described the expression of ILI7 in different subsets
Table 2 The correlation of estrogen receptor, progesterone receptor, and Human epidermal receptor-2 expression with IL17 expression in the breast lesions

\begin{tabular}{lccc}
\hline & Pearson's $r$ & P value & $\begin{array}{l}\text { 95\% Cl [Lower } \\
\text { bound-upper } \\
\text { bound] }\end{array}$ \\
\hline Estrogen receptor & -0.001 & 0.993 & $2.70[1.44-3.96]$ \\
Progesterone receptor & -0.024 & 0.813 & $2.93[1.65-4.21]$ \\
Human epidermal receptor-2 & 0.043 & 0.679 & $2.83[1.66-3.98]$ \\
\hline
\end{tabular}

of benign and malignant lesions of the breast. Notably, malignant cases had strong positive expression in both number of cells and intensity of the reaction

Table 1 Relationship of different variables in study population with IL17 expression

\begin{tabular}{|c|c|c|c|c|c|c|}
\hline & \multicolumn{4}{|l|}{ IL17 expression } & \multirow[t]{2}{*}{ Total $(n=137)$} & \multirow[t]{2}{*}{$P$ value } \\
\hline & No expression & Mild & Moderate & Strong & & \\
\hline \multicolumn{7}{|l|}{ Age group } \\
\hline Not more than 20 & $1(100 \%)$ & $0(0.0 \%)$ & $0(0.0 \%)$ & $0(0.0 \%)$ & $1(0.7 \%)$ & \multirow[t]{4}{*}{0.065} \\
\hline 21 to 40 years & $13(43.3 \%)$ & $5(16.7 \%)$ & $7(23.3 \%)$ & $5(16.7 \%)$ & $30(21.9 \%)$ & \\
\hline 41 to 60 years & $38(44.7 \%)$ & $13(15.3 \%)$ & $9(10.6 \%)$ & $25(29.4 \%)$ & $85(62.0 \%)$ & \\
\hline Above 60 years & $5(29.4 \%)$ & $2(11.8 \%)$ & $8(47.1 \%)$ & $2(11.8 \%)$ & $17(12.4 \%)$ & \\
\hline \multicolumn{7}{|l|}{ Tumor type } \\
\hline Benign & $23(57.5 \%)$ & $0(0.0 \%)$ & $10(25.0 \%)$ & $7(17.5 \%)$ & $40(29.2 \%)$ & \multirow[t]{2}{*}{0.002} \\
\hline Malignant & $34(34.1 \%)$ & $22(22.7 \%)$ & $15(15.5 \%)$ & $26(26.8 \%)$ & $97(70.8 \%)$ & \\
\hline \multicolumn{7}{|c|}{ Diagnosis of breast lesion } \\
\hline IDC & $30(34.5 \%)$ & $19(21.8 \%)$ & $13(14.9 \%)$ & $25(28.7 \%)$ & $87(63.5 \%)$ & \multirow[t]{8}{*}{0.035} \\
\hline $\mathrm{DE}$ & $7(63.6 \%)$ & $0(0.0 \%)$ & $4(36.4 \%)$ & $0(0.0 \%)$ & $11(8.0 \%)$ & \\
\hline FA & $12(57.1 \%)$ & $0(0.0 \%)$ & $6(28.6 \%)$ & $3(14.3 \%)$ & $21(15.3 \%)$ & \\
\hline FC & $2(50.0 \%)$ & $0(0.0 \%)$ & $0(0.0 \%)$ & $2(50.0 \%)$ & $4(2.9 \%)$ & \\
\hline IDCS & $2(66.7 \%)$ & $1(33.3 \%)$ & $0(0.0 \%)$ & $0(0.0 \%)$ & $3(2.2 \%)$ & \\
\hline ILC & $2(28.6 \%)$ & $2(28.6 \%)$ & $2(28.6 \%)$ & $1(14.3 \%)$ & $7(5.1 \%)$ & \\
\hline Lipoma & $2(100 \%)$ & $0(0.0 \%)$ & $0(0.0 \%)$ & $0(0.0 \%)$ & $2(1.5 \%)$ & \\
\hline PTS & $0(0.0 \%)$ & $0(0.0 \%)$ & $0(0.0 \%)$ & $2(100 \%)$ & $2(1.5 \%)$ & \\
\hline \multicolumn{7}{|l|}{ ER } \\
\hline Mild & 10 (37.0\%) & 7 (25.9\%) & $3(11.1 \%)$ & $7(25.9 \%)$ & 27 (19.7\%) & \multirow[t]{4}{*}{0.678} \\
\hline Moderate & $3(21.4 \%)$ & $4(28.6 \%)$ & $4(28.6 \%)$ & $3(21.4 \%)$ & $14(10.2 \%)$ & \\
\hline Strong & $5(29.4 \%)$ & $5(29.4 \%)$ & $1(5.9 \%)$ & $6(35.3 \%)$ & 17 (12.4\%) & \\
\hline No expression & 16 (41.0\%) & $6(15.4 \%)$ & $7(17.9 \%)$ & $10(25.6 \%)$ & 39 (28.5\%) & \\
\hline \multicolumn{7}{|l|}{ PR } \\
\hline Mild & $9(37.5 \%)$ & $6(25.0 \%)$ & $3(12.5 \%)$ & $6(25.0 \%)$ & $24(17.5 \%)$ & \multirow[t]{4}{*}{0.623} \\
\hline Moderate & $3(30.0 \%)$ & $3(30.0 \%)$ & $1(10.0 \%)$ & $3(30.0 \%)$ & $10(7.3 \%)$ & \\
\hline Strong & $1(8.3 \%)$ & $3(25.0 \%)$ & $2(16.7 \%)$ & $6(50.0 \%)$ & $12(8.8 \%)$ & \\
\hline No expression & $21(41.2 \%)$ & 10 (19.6\%) & $9(17.6 \%)$ & $11(21.6 \%)$ & $51(37.2 \%)$ & \\
\hline \multicolumn{7}{|l|}{ HER2 } \\
\hline Mild & $7(35.0 \%)$ & 7 (35.0\%) & $0(0.0 \%)$ & $6(30.0 \%)$ & $20(14.6 \%)$ & \multirow[t]{4}{*}{0.361} \\
\hline Moderate & $7(46.7 \%)$ & $2(13.3 \%)$ & $3(20.0 \%)$ & $3(20.0 \%)$ & 15 (10.9\%) & \\
\hline Strong & $8(33.3 \%)$ & $3(12.5 \%)$ & $4(16.7 \%)$ & $9(37.5 \%)$ & $24(17.5 \%)$ & \\
\hline No expression & $12(31.6 \%)$ & $10(26.3 \%)$ & $8(21.1 \%)$ & $8(21.1 \%)$ & 38 (27.7\%) & \\
\hline
\end{tabular}

ER estrogen receptor, $P R$ progesterone receptor, HER2 Human epidermal receptor-2 
when compared with the benign ones. These findings were consistent with previous exhaustive studies pointing that $I L 17$ is more associated with malignant breast lesions [23-25]. The variation in the staining patterns between IDC and IDCS found in this study can be useful in differentiation between the two BC classes. IDC can show moderate and strong expression of IL17 compared to IDCS. These patterns variation might be attributed to the high numbers of infiltrating IL17-producing cells in IDC [9]. Similar results were also stated in malignant and benign lesions in the thyroid and salivary gland cancers $[26,27]$.

Benign lesions in this study were found to produce considerable levels of IL17 in epithelial cells of normal ducts and lobules; the highest production was detected in PTS and FA. Nonetheless, the data regarding cytokines expression in benign tumors is limited and strongly focused on FA subset of benign tumor [28]. Thus, to our knowledge, this study is among the first to address $I L 17$ among other breast lesions. Positive expression was also obtained in DE and FC in which expression was restricted to the inflammatory cells and stroma. In DE, the large numbers of macrophages foamy cells expressing $I L 17$ might be attributed, mainly, to the inflammatory reactions associated with this condition [29].

The majority of studies demonstrated in situ expression of IL17 in breast cancer along with T lymphocyte and innate immune cells being the main expression site for this cytokine in other types of cancers [30-32]. Recently IL17 was shown to be expressed by other cells like plasma cells and paneth cells in gut [33,34]. In the current study the main site of $I L 17$ expression was malignant cells themselves in addition to tumor stroma. This finding is in accordance with Li et al. [35] and Al-Samadi et al. [36] who found high prevalence of breast cancer and colon cancer cells expressing IL17, correspondingly.

Regarding the association between IL17 expression and hormonal expression (ER, PR and HER2) among malignant cases, the obtained results disclose no significant association between $I L 17$ expression in breast tissue and the previously mentioned receptors ( $P$ values $>0.05$ ) Conversely to our study, IL17 was more associated with ER- and triple negative BC $[9,15]$. However, in concordance to our study Chavey et al. [20] found that IL17 is one of the cytokines that are not related with steroid receptors expression. Furthermore, Slattery et al. [37] found that the relationship between cytokines and steroid receptors expression is affected by particular variants of cytokines with no association between $I L 17$ variants and these receptors expression in the breast. Therefore, these results indicate that $I L 17$ role in breast cancer might be independent of hormonal receptors expression.

\section{Conclusion}

IL17 is expressed in a variety of cell types including benign and malignant cells; mostly tumor cells and tumor associated stromal cells. Malignant cells significantly express higher levels of IL17 compared to benign tumor cells. IL17 expression in BC might be independent of hormonal receptors expression.

\section{Limitations}

- This study evaluated the expression of IL17 in a small cohort of breast lesions, including benign and malignant lesions without providing dual staining to specify cells types.

\section{Abbreviations}

BC: Breast cancer; DE: Duct ectasia; ER: Estrogen receptor; FA: Fibro-adenomas; FC: Fibrocystic change; HER2: Human epidermal receptor-2; IDC: Invasive ductal carcinoma; IDCS: Intraductal carcinoma in situ; IL 17: Interleukin-17; ILC: Invasive lobular carcinoma; PBS: Phosphate buffer saline; PR: Progesterone receptor; PTS: Benign phyllodes tumor.

\section{Acknowledgements}

We gladly thank the staff of Medical Laboratory Sciences, University of Khartoum for their support and great help. And also great thanks to all participants contributed to this work.

\section{Authors' contributions}

ETA and MAMM performed samples collection and immunohistochemical technique regarding tissue samples. ETA, EES and AMME performed scoring and interpretation of immunohistochemical staining. MAMM, EES and AMME performed general supervision and guidance in the research process. ETA, EES, NSM, AA, and MSM performed data analysis and interpretation, ETA, EES, and NSM drafted the manuscript. All authors read and approved the final manuscript.

\section{Funding}

Not applicable.

\section{Availability of data and materials}

The datasets used and/or analyzed during the current study are available from the corresponding author on reasonable request.

\section{Ethics approval and consent to participate}

Samples collection and conduction of the study was approved by the Faculty of Medical Laboratory Sciences Research Ethics Committee-University of Khartoum, Sudan. Informed consent was obtained from each participant prior to hospital enrollment using writing and verbal informed consent in case of illiterate patients.

\section{Consent to publish}

Not applicable.

\section{Competing interests}

The authors declare that they have no competing interests.

\section{Author details}

${ }^{1}$ Department of Histopathology and Cytology, Faculty of Medical Laboratory Sciences, University of Khartoum, Khartoum, Sudan. ${ }^{2}$ Department of Histopathology and Cytology, Faculty of Medical Laboratory Sciences, National University, Khartoum, Sudan. ${ }^{3}$ Molecular Biology Department, Faculty of Zoology, 
University of Khartoum, Khartoum, Sudan. ${ }^{4}$ Mycetoma Research Center, University of Khartoum, Khartoum, Sudan. ${ }^{5}$ School of Medicine, Nile College, Khartoum, Sudan. ${ }^{6}$ Department of Histopathology and Cytology, Alfarrabi College for Science and Technology, Khartoum, Sudan. ${ }^{7}$ Institute of Endemic Diseases, University of Khartoum, Khartoum, Sudan. ${ }^{8}$ Department of Neurology, Mayo Clinic, Jacksonville, FL, USA. ${ }^{9}$ Department of Radiology, Mayo Clinic, Jacksonville, FL, USA. ${ }^{10}$ Department of Internal Medicine, Faculty of Medicine, University of Khartoum, Khartoum, Sudan. ${ }^{11}$ Department of Parasitology and Medical Entomology, Alfarrabi College for Science and Technology, Khartoum, Sudan. ${ }^{12}$ Department of Parasitology and Medical Entomology, Faculty of Medical Laboratory Sciences, Nile University, Khartoum, Sudan. ${ }^{13}$ Department of Parasitology, Faculty of Medicine, Sinnar University, Sinnar, Sudan.

${ }^{14}$ Department of Histopathology and Cytology, Faculty of Applied Medical Sciences, University of Bisha, Bisha, Kingdom of Saudi Arabia.

Received: 26 May 2020 Accepted: 17 June 2020

Published online: 23 June 2020

\section{References}

1. Azim HA, Partridge AH. Biology of breast cancer in young women. Breast Cancer Res. 2014;16:427.

2. Lodge M, Corbex M. Establishing an evidence-base for breast cancer control in developing countries. Breast. 2011;20:565-9.

3. Shaaban A, Sloane J, West C, Moore F, Jarvis C, Williams E, Foster C. Histopathologic types of benign breast lesions and the risk of breast cancer: case-control study. Am J Surg Pathol. 2002;26:421-30.

4. Weigelt B, Peterse JL, Van't Veer LJ. Breast cancer metastasis: markers and models. Nat Rev Cancer. 2005;5:591-602.

5. Gelaleti GB, Jardim BV, Leonel C, Moschetta MG, de Campos Zuccari DAP. Interleukin-8 as a prognostic serum marker in canine mammary gland neoplasias. Vet immunol Immunopathol. 2012;146:106-12.

6. Al-Hassan A, Al-Ghurabi B, Al-Karkhi I. Prognostic value of proinflammatory cytokines in breast cancer. Biomol Res Ther. 2012;1:2.

7. Ueno T, Toi M, Saji H, Muta M, Bando H, Kuroi K, Koike M, Inadera H, Matsushima K. Significance of macrophage chemoattractant protein-1 in macrophage recruitment, angiogenesis, and survival in human breast cancer. Clin Cancer Res. 2000;6:3282-9.

8. Guo Y, Xu F, Lu T, Duan Z, Zhang Z. Interleukin-6 signaling pathway in targeted therapy for cancer. Cancer Treat Rev. 2012;38:904-10.

9. Chen WC, Lai YH, Chen HY, Guo HR, Su IJ, Chen HH. Interleukin-17-producing cell infiltration in the breast cancer tumour microenvironment is a poor prognostic factor. Histopathology. 2013;63:225-33.

10. Numasaki M, Fukushi J-I, Ono M, Narula SK, Zavodny PJ, Kudo T, Robbins PD, Tahara H, Lotze MT. Interleukin-17 promotes angiogenesis and tumor growth. Blood J Am Soc Hematol. 2003;101:2620-7.

11. Feng M, Wang Y, Chen K, Bian Z, Wu J, Gao Q. IL-17A promotes the migration and invasiveness of cervical cancer cells by coordinately activating MMPs expression via the p38/NF-kB signal pathway. PLoS ONE. 2014;9.

12. McAllister F, Bailey JM, Alsina J, Nirschl CJ, Sharma R, Fan H, Rattigan Y, Roeser JC, Lankapalli RH, Zhang H. Oncogenic Kras activates a hematopoietic-to-epithelial IL-17 signaling axis in preinvasive pancreatic neoplasia. Cancer Cell. 2014;25:621-37.

13. Chang SH. Tumorigenic Th17 cells in oncogenic Kras-driven and inflammation-accelerated lung cancer. Oncoimmunology. 2015;4:e955704.

14. Jiang Y, Yang S, Li P, Luo X, Li Z, Hao Y, Yu P. The promotion of the transformation of quiescent gastric cancer stem cells by $\mathrm{LL}-17$ and the underlying mechanisms. Oncogene. 2017;36:1256-64.

15. Cochaud S, Giustiniani J, Thomas C, Laprevotte E, Garbar C, Savoye A-M, Curé H, Mascaux C, Alberici G, Bonnefoy N. IL-17A is produced by breast cancer TILs and promotes chemoresistance and proliferation through ERK1/2. Sci Rep. 2013;3:3456.

16. Park WC, Sung KS, Kim JS, Oh SJ, Choi SH, You YK, Chun HM, Kim IC, Jung SS. Prognostic significance of hormonal receptors in very young women with early breast cancer. J Korean Breast Cancer Soc. 2002;5:319-22.

17. Vorherr H. Endocrinology of breast cancer. Maturitas. 1987;9:113-22.

18. Hoang T, Rattan R. Common uses of immunohistochemistry in interpreting lesions of the breast: a pictorial review. Breast Cancer Res. 2008;10:P87.
19. Ramirez F, Fowell D, Puklavec M, Simmonds S, Mason D. Glucocorticoids promote a Th2 cytokine response by CD4+T cells in vitro. I Immunol. 1996;156:2406-12.

20. Chavey C, Bibeau F, Gourgou-Bourgade S, Burlinchon S, Boissière F, Laune $D$, Roques $S$, Lazennec $G$. Oestrogen receptor negative breast cancers exhibit high cytokine content. Breast Cancer Res. 2007;9:R15.

21. Allred D, Harvey JM, Berardo M, Clark GM. Prognostic and predictive factors in breast cancer by immunohistochemical analysis. Mod Pathol. 1998;11:155-68.

22. Wolff AC, Hammond MEH, Schwartz JN, Hagerty KL, Allred DC, Cote RJ, Dowsett M, Fitzgibbons PL, Hanna WM, Langer A. American Society of Clinical Oncology/College of American Pathologists guideline recommendations for human epidermal growth factor receptor 2 testing in breast cancer. Archiv Pathol Lab Med. 2007;131:18-43.

23. Autenshlyus A, Kunts T, Karpukhina K, Mikhaylova E, Varaksin N, Marinkin I, Lyakhovich V. Cytokine pattern of the breast tumor supernatant. Doklady biological sciences. Berlin: Springer; 2016. p. 247-8.

24. Borj MR, Andalib AR, Mohammadi A, Hoseiniharouni SM, Pourghadamyari H, Azizi H, Golmahammadi T, Ghahfarokhy KM. Evaluation of IL-4, IL-17, and IFN-y levels in patients with breast cancer. Int J Basic Sci Med. 2017:2:20-4.

25. Carvalho G, Faria D, Zanetti BR, Miranda L, Hassumi-Fukasawa MK, Miranda-Camargo F, Crispim JCO, Soares EG. High IL-17 expression is associated with an unfavorable prognosis in thyroid cancer. Oncol Lett. 2017:13:1925-31.

26. Haghshenas MR, Khademi B, Faghih Z, Ghaderi A, Erfani N. Immune regulatory cells and IL17-producing lymphocytes in patients with benign and malignant salivary gland tumors. Immunol Lett. 2015;164:109-16.

27. Elgaili EM, Abuidris DO, Rahman M, Michalek AM, Mohammed SI. Breast cancer burden in central Sudan. Int J Women's Health. 2010;2:77.

28. Gary MT, Chaiwun B, Lau K-M, Scolyer R, Lee CS, Karim RZ, Putti TC, Law BK, Lui PC, Tan PH. Endothelin-1 expression correlates with atypical histological features in mammary phyllodes tumours. J Clin Pathol. 2007;60:1051-6.

29. Dixon J, Ravisekar O, Chetty U, Anderson TJ. Periductal mastitis and duct ectasia: different conditions with different aetiologies. Br I Surg. 1996;83:820-2.

30. Kuang DM, Peng C, Zhao Q, Wu Y, Chen MS, Zheng L. Activated monocytes in peritumoral stroma of hepatocellular carcinoma promote expansion of memory Thelper 17 cells. Hepatology. 2010;51:154-64.

31. Guéry L, Hugues S. Th17 cell plasticity and functions in cancer immunity. BioMed Res Int. 2015;2015.

32. Wu S, Rhee K-J, Albesiano E, Rabizadeh S, Wu X, Yen H-R, Huso DL, Brancati FL, Wick E, McAllister F. A human colonic commensal promotes colon tumorigenesis via activation of $\mathrm{T}$ helper type $17 \mathrm{~T}$ cell responses. Nat Med. 2009;15:1016

33. Takahashi N, Vanlaere I, De Rycke R, Cauwels A, Joosten LA, Lubberts E, van den Berg WB, Libert C. IL-17 produced by Paneth cells drives TNFinduced shock. J Exp Med. 2008;205:1755-61.

34. Schlegel PM, Steiert I, Kötter I, Müller CA. B cells contribute to heterogeneity of IL-17 producing cells in rheumatoid arthritis and healthy controls. PloS ONE. 2013;8

35. Li YX, Zhang L, Simayi D, Zhang N, Tao L, Yang L, Zhao J, Chen YZ, Li F, Zhang WJ. Human papillomavirus infection correlates with inflammatory Stat3 signaling activity and IL-17 level in patients with colorectal cancer. PLOS ONE. 2015;10.

36. Al-Samadi A, Moossavi S, Salem A, Sotoudeh M, Tuovinen SM, Konttinen YT, Salo T, Bishehsari F. Distinctive expression pattern of interleukin-17 cytokine family members in colorectal cancer. Tumor Biol. 2016:37:1609-15.

37. Slattery ML, Herrick JS, Torres-Mejia G, John EM, Giuliano AR, Hines LM, Stern MC, Baumgartner KB, Presson AP, Wolff RK. Genetic variants in interleukin genes are associated with breast cancer risk and survival in a genetically admixed population: the Breast Cancer Health Disparities Study. Carcinogenesis. 2014;35:1750-9.

\section{Publisher's Note}

Springer Nature remains neutral with regard to jurisdictional claims in published maps and institutional affiliations. 